\section{Karyna OLIINICHENKO}

\section{ENVIRONMENTAL \\ PROTECTION AND A DYMANIC INTERPRETATION OF EUROPEAN CONVENTION ON HUMAN RIGHTS}

\begin{abstract}
Стаття стосується розвитку практики Свропейського суду з прав людини в тлумаченні статті 8 Свропейської конвенції про захист прав людини та основоположних свобод 3 огляду на екологічні проблеми. Це дослідження фокусується на тому, як екологічні проблеми погіршують право на повагу до приватного та сімейного життя, гарантованих Конвенцією.

Ключові слова: Європейський суд з прав людини, захист навколишнього середовища, приватне життя, сімейне життя, динамічне тлумачення, свобода розсуду.
\end{abstract}

The article concerns the development of practice of the European Court of Human Rights in the interpretation of Article 8 of the European Convention on protection of Human Rights and fundamental Freedoms in the light of environmental problems. This research focuses on how environmental problems impair the rights to respect for private and family life guaranteed under the Convention.

Keywords: European Court of Human Rights, environmental protection, private life, family life, dynamic interpretation, margin of appreciation.

In recent decades the environment and environmental issues have become a concern of the mankind. It influenced not only the environmental law, but also other branches such as international law of human rights. Now it is obvious that protection of human rights and preservation of environment alongside with achievement of peace and security in the world are the fundamental values of modern society. The two interrelated issues of human rights and environmental protection emerged as a matter of international concern in the second half of XX century, namely after 1972 Stockholm Conference on the Human Environment. On the European level the preservation of the environment became possible with the implementation of the European Convention on Human Rights (hereinafter - the Convention) adopted in 1950. The Convention and Additional Protocols have enshrined numerous human rights and freedoms but no mention of any right to the environment can be found there. There is no surprise as the Convention was signed in 1950 long before the humanity raised the question of environmental protection.

But the European Court of Human Rights (hereinafter - ECHR) itself reaffirmed in a list of cases that bad environmental conditions could interfere with the effective enjoyment of the rights and freedoms enshrined in the Convention [1, p. 8]. These environmental factors can affect individual rights in three different ways:

1. Human rights can be directly affected by the poor environmental conditions. In this case the authority has a positive obligation to ensure the respect for human rights;

2. Adverse environmental factors may give rise to the procedural rights of a person, such as right to information and taking part in decision-making process;

3. The protection of the environment may be a legitimate aim justifying interference with human rights $[2$, p. $7-8]$

Despite the fact that the Convention does not deal with environmental issues at all, the ECHR in its practice considers the relations between human rights and environment. The point is that the Convention is a living instrument containing standards instead of detailed rules and should be interpreted in the context of present day situation. This is achieved through dynamic (or evolutive) interpretation. This interpretation

УДК: $341.1 / 8$

https://doi.org/10.36952/uail.2020.1.50-52

() K. A. Oliinichenko
OLIINICHENKO Karyna Anatoliivna

4th year student of international law of the

Institute of International Relations

of Taras Shevchenko National University of Kyiv 
helps to maintain the effectiveness of the Convention. Dynamic interpretation provides a necessary degree of flexibility to human rights law in a changing environment [3, p. 1732]. This approach is consistent with the purpose of the Convention to secure to everyone the rights and freedoms set forth therein. Professor Jannek Gerards believes that dynamic approach means that the Convention should be interpreted according to its object and purpose [3, p. 1739]. In accordance with the Preamble "the aim of the Council of Europe is the achievement of greater unity between its Members and the maintenance and further realization of rights and freedoms is one of the methods for its achievement" [4]. Convention as a living instrument enhances the effectiveness of human rights and ensures its realization [3, p. 1739].

Earlier when the question of admissibility had to be decided by the European Commission of Human Rights the applications concerning environmental issues were dismissed because of the ill-founded ratio materiae as there is no right to environment in the Convention. Nowadays, given the dynamic interpretation, more and more cases brought before the ECHR concern the relation between protection of human rights and preservation of the environment. So, even if there is no explicit right to the clear and safe environment, the case law of the ECHR has shown the great concern of a link between environmental protection and the rights and freedoms of individuals.

Among other such cases concern the right to respect for private and family life guaranteed under Article 8 of the Convention. Paragraph 1 establishes that "Everyone has the right to respect for his private and family life, his home and his correspondence" [4; p. 11]. It is worth mentioning that environmental degradation does not necessarily involve the violation of Article 8 since it does not include an express right to environmental protection [2; p. 19]. For Article 8 to be invoked the two questions must be examined by the Court - firstly, a causal link between the activity and the negative impact on the individual and secondly, the level of threshold of harm which depends on particular circumstances of each case. Besides, paragraph 2 of the Article in question establishes the conditions to be met where decision of public authority affects the environment to the extent that there is an interference with the right to respect for private life and family. Such decisions must be

1. made in accordance with the law;

2. necessary in the democratic society in the interest of national security, public safety or the economic well-being of the country;

3. made for the prevention of disorder or crime, for the protection of health or morals or for protection of rights and freedoms of others.

The Court has also to assess whether the public authority has approached the due diligence and has taken all competing interests into consideration [2, p. 20].

In numerous cases the ECHR has confirmed that "severe environmental pollution" such as toxic emissions from a factory, fumes and noise from an airport, smells from a factory can interfere with person's enjoyment of his or her home and private life. For instance, a lot of cases concern noise pollution. In Arrondelle v. United Kingdom case the applicant complained of noise from the Gatwick Airport and a nearby motorway. It was settled with a payment of 7500 pounds for the applicant [5, p. 385]. Similar case Powell and Raynor v. United Kingdom also concerned noise from the Heathrow Airport. The Applicants claimed that "as a result of excessive noise generated by air traffic in and out of Heathrow Airport, they had each been victim of an unjustified interference by the United Kingdom with the right guaranteed by Article 8". The Court found the violation of Article 8(1) but the UK was justified under Article 8(2) stating that "the existence of large international airports, even in densely populated urban areas, and the increasing use of jet aircraft have without question become necessary in the interests of a country's economic well-being". Additionally, the government has introduced a number of measures "to control, abate and compensate for aircraft noise including aircraft noise certification, restrictions on night jet movements, noise monitoring and the introduction of noise preferential routes" [6].

Not only noise interferes with the enjoyment of right to respect for private and family life. Lopez-Ostra v. Spain is a vivid example of the judgement of the Court on pollution as a breach of the right provided for in Article 8. In this case the applicant claimed that the fumes and pollution from a waste treatment plant next to her house caused health problems and inconveniences for her family. The plant was opened in 1988 without any permit and license. Immediately after the opening the plant began releasing gas fumes and contamination, which caused nuisance to people living nearby. During a period of three years people suffered from the pollution and finally had to move because of the health problems. In the opinion of the authorities pollution did not constitute a grave health risks and therefore breach of individuals' rights. However, the ECHR found the violation of Article 8. In this case the Court applied the "margin of appreciation" doctrine which allows the state certain discretion in determining the balance between the interests of the state and of the individual. But Spain had exceeded its "margin of appreciation" because "the State did not succeed in striking a fair balance between the interest of the town's economic well-being - that of having a waste- 
treatment plant - and the applicant's effective enjoyment of her right to respect for her home and her private and family life" [7].

Also a striking example of the authorities' inaction is Dubetska and Other v. Ukraine case. The applicants living near the state-owned coal mine complained that they suffered and their house and living environment were damaged by the activity of the mine. The Court recognized that it is often hard to distinguish the impact of the environmental hazards and other factors. In the present case the applicants were living in an unsafe area. But the important thing is that the state for twelve years has not found the effective solution to the applicants' problems. So, having found the violation of Article 8 the Court established the Ukrainian Government's obligation to find the resolution to the applicants' problems [8].

The preservation of environment in the framework of planning activities can be a legitimate aim justifying certain restrictions imposed on an individual concerning his rights under Article 8. In Chapman v. the United Kingdom the applicant was refused to remain in caravan (the applicant is a Roma) on her own land because according to the policy this land was to be preserved and no dwellings were allowed there. The Court recognized that this act interfered with the right under Article 8 but it pursued the legitimate aim of protecting the rights of others by preserving the environment for the benefit of current and future generations. However, the actions have to be proportionate to the aim [2, p. 59-60].

Therefore, by means of Article 8 people protect not only their fundamental rights but also preserve the environment because the authorities must eliminate the cause and the consequences of the act violating human rights - namely pollution, noise, contaminations, toxins and so on. The protection of human rights under Article 8 is an indirect way of protecting the environment and achieving the goals of sustainable development. The dynamic interpretation together with developments in international and domestic law of each state in respect of environmental protection provides support for the Court to protect the human rights while protecting the environment. Such practice gives a powerful impulse to the development of international environmental law as well as international law of human rights. Now we are the witnesses of greening of the international law in whole and the ECHR in particular and finding a balance between human rights and environmental protection.

1. Daniel García San José. Environmental protection and the European Convention on Human Rights / Daniel García San José. - Strasbourg: Council of Europe Publishing, 2005. - 75 p.

2. Manual on human rights and the environment - Strasbourg: Council of Europe Publishing, 2012. - 195 p.

3. Dzehtsiarou K. European Consensus and the Evolutive Interpretation of the European Convention on Human Rights / Kanstantsin Dzehtsiarou / / German Law Journal / Kanstantsin Dzehtsiarou., 2011. P. 1730-1745.

4. European Convention on human Rights [Electronic resource] -access to the resource: https://www. echr.coe.int/Documents/Convention_ENG.pdf.

5. Kiss A. International environmental law / A. Kiss, D. Shelton. - Ardsley: Transnational Publisher, 2004. $-446 \mathrm{p}$.

6. CASE OF POWELL AND RAYNER v. THE UNITED KINGDOM [Electronic resource] - access to the resource: https://www.legal-tools.org/en/browse/record/e1b3ec/.

7. CASE OF LÓPEZ OSTRA v. SPAIN [Electronic resource] - access to the resource: https://hudoc.echr. coe.int/eng\#\{\%22itemid $\% 22:[\% 22001-57905 \% 22]\}$.

8. CASE OF DUBETSKA AND OTHERS v. UKRAINE [Electronic resource] - access to the resource: http://hudoc.echr.coe.int/eng?i=001-103273. 